BSGF - Earth Sciences Bulletin 2019, 190, 5

(C) B. Musavu Moussavou, Published by EDP Sciences 2019

https://doi.org/10.1051/bsgf/2019006

Available online at: www.bsgf.fr

\title{
Albian bivalves from Madiela Formation in north Gabonese coastal basin
}

\author{
Benjamin Musavu Moussavou* \\ Université des Sciences et Techniques de Masuku, département de géologie et URESTE, BP 943, Franceville, Gabon
}

Received: 11 May 2018 / Accepted: 9 April 2019

\begin{abstract}
A study of Albian bivalves from Madiela Formation in north of Gabonese coastal basin has been carried out from N'Toum quarry geological section. Four genera including six species are identified: Liopistha (Psilomya) sp. 1, ? Liopistha (Psilomya) sp. 2, Megaporomya sp., Neithea (Neithea) dutrugei (Coquand, 1862), Pleuromya sp. 1 and Pleuromya sp. 2. One morphotype is identified as Bivalvia gen. et sp. indet. The genus Megaporomya Ayoub-Hannaa et al., 2013 and all identified species, except Neithea (Neithea) dutrugei (Coquand, 1862), are found for the first time in Gabonese coastal basin. Now, a total of twelve species of bivalves have been reported from the Madiela Formation. In Gabon, the presence for the first time of genera Liopistha and Pleuromya in N'Toum quarry geological section which is assigned to the Albian permits us to expand their geographical distribution until N'Toum region, and their age range to Albian.
\end{abstract}

Keywords: Albian / Madiela Formation / bivalves / Gabonese coastal basin

Résumé - Les bivalves albiens de la Formation du Madiela dans le bassin côtier nord-gabonais. Une étude portant sur les bivalves de la Formation du Madiéla dans le bassin côtier nord gabonais a été menée à partir de la coupe de la carrière de N'Toum. Quatre genres incluant six espèces ont été identifiés : Liopistha (Psilomya) sp. 1, ? Liopistha (Psilomya) sp. 2, Megaporomya sp., Neithea (Neithea) dutrugei (Coquand, 1862), Pleuromya sp. 1 et Pleuromya sp. 2. Un morphotype est identifié comme Bivalvia gen. et sp. indet. Le genre Megaporomya Ayoub-Hannaa et al., 2013 et l'ensemble des espèces identifiées, à l'exception de Neithea (Neithea) dutrugei (Coquand, 1862), sont trouvés ici pour la première fois dans le bassin côtier gabonais. On dénombre actuellement douze espèces de bivalves dans la Formation du Madiéla. Au Gabon, les distributions stratigraphique et géographique des genres Liopistha et Pleuromya sont étendues respectivement jusqu'à l'Albien et dans la région de N'Toum.

Mots clés : Albien / Formation du Madiela / bivalves / bassin côtier gabonais

\section{Introduction}

The Gabonese coastal basin is one of the West Africa coastal basins which extend from Cameroon to Angola-Namibia and contains sediments with different geological stories. The tectonic and sedimentary evolution (Mbina Mounguengui, 1998; Mbina Mounguengui et al., 2002; Mbina Mounguengui and Lang, 2003) allow to recognize three phases: a prerift phase (PrecambrianJurassic), a rift phase (Neocomian-Barremian) and a drift phase (Aptian-present). Prerift and rift phases are characterized mainly by continental, lacustrine and fluvial sediments whereas the drift phase is characterized by marine sediments.

The drift phase contents several formations. Among these, there is the Madiela Formation (Albian) which occurs in N'Toum

\footnotetext{
*Corresponding author: musavu@yahoo.fr
}

region. The stratigraphical framework, together with the palaeontological value of the Madiela Formation have been discussed by several authors such as: Choubert (1935), Hourcq and Hausknecht (1954), Dartevelle and Brébion (1956), Dartevelle and Freneix (1957), Hudeley and Belmonte (1970), Teisserenc and Villemin (1990), Chevalier et al. (2002), Musavu Moussavou and Mabicka Obame (2015). Systematic descriptions of the bivalve fauna from the Madiela Formation have been carried out only by Dartevelle and Freneix (1957). Other authors listed and mentioned only the presence of this fauna without descriptions and illustrations. Six species have been reported from the Madiela Formation of Gabon namely: Lopha (?) dieneri (Blanckenhorn, 1890), Panopea cf. gurgites d'Orbigny, 1844, Pinna decussata Goldfuss, 1837, Pseudolimea neglecta (Tate in Dartevelle and Freneix, 1957), Pterotrigonia scabra (Lamarck, 1819) and Neithea shawi Pervinquière, 1912 (=Neithea (Neithea) dutrugei (Coquand, 1862) herein). 

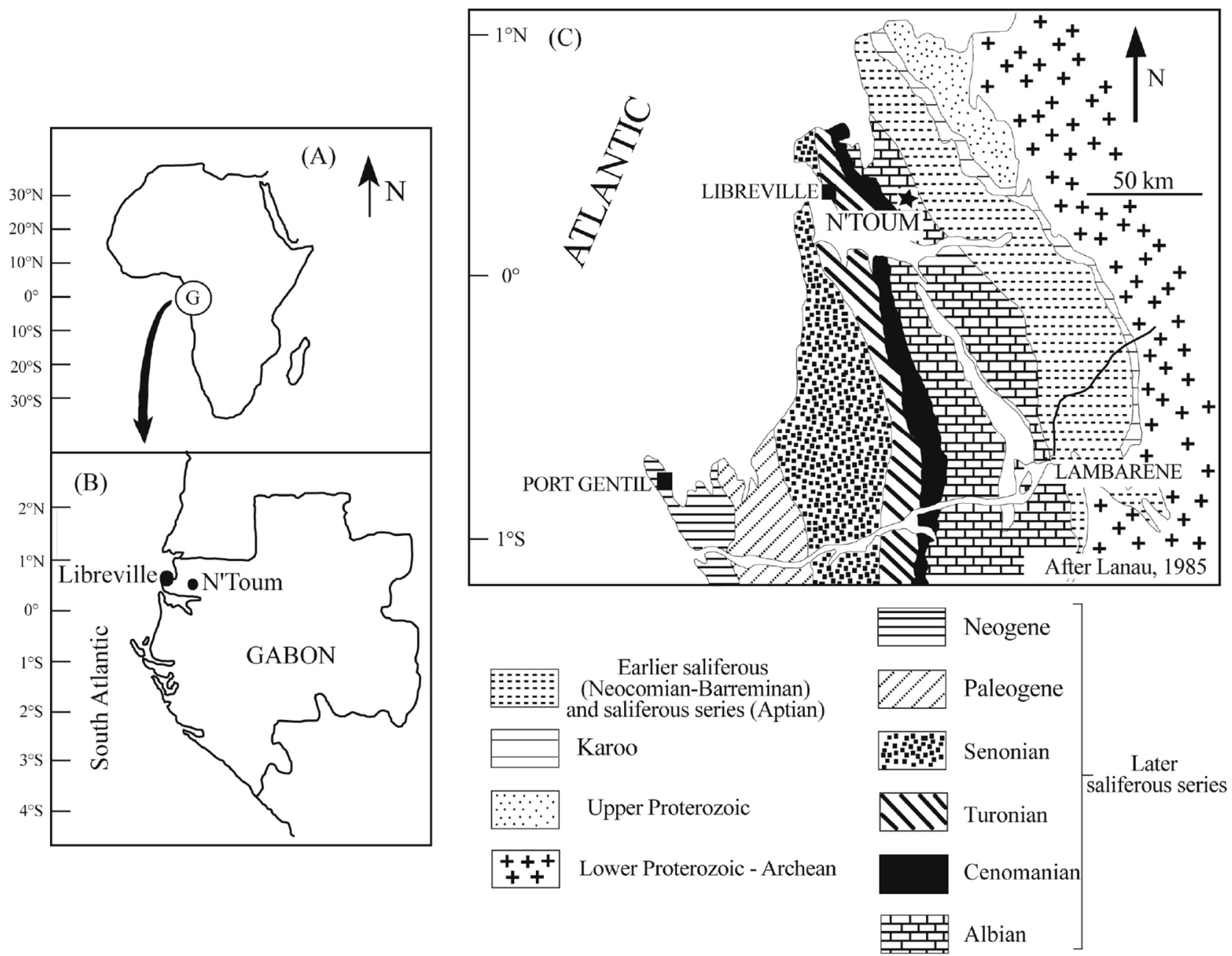

Fig. 1. Location map of Gabon (A) and N'Toum locality (B) and geological map of north Gabonese coastal basin (C). Geological map after Lanau (1985).

The aim of this study is to:

- provide, after half a century, systematic descriptions;

- present the new diversity;

- discuss the distribution and stratigraphy of the bivalve fauna from the Madiela Formation based on new data from N'Toum quarry section.

\section{Geological setting}

The Madiela Formation overlies the Ezanga Formation (Aptian) and is in turn overlain by the Cap Lopez Formation (Cenomanian) throughout most of the coastal basin of Gabon, with a maximum thickness of $2050 \mathrm{~m}$ (Teisserenc and Villemin, 1990). In the eastern part of the basin, the Madiela Formation occupies the centre of the graben and was deposited in a marine to deltaic environment (Chevalier et al., 2002). It is composed of dolomitized carbonates, shales, clays, silts, sandstones and marls. In the western part of the basin, the Madiela Formation consists of shales and carbonaceous shales (Teisserenc and Villemin, 1990; Chevalier et al., 2002). From a paleontological point of view, the Madiela Formation includes foraminifera, ostracods, gastropods, ammonites, calcareous nannofossils, bivalves and echinoids
(Choubert, 1935; Hourcq, 1952; Dartevelle and Brébion, 1956; Dartevelle and Freneix, 1957; Hudeley and Belmonte, 1970; Grosdidier, 1979; Dupont, 1996; Chevalier et al., 2002; Musavu Moussavou and Mabicka Obame, 2015).

The N'Toum quarry geological section (Figs. 1 and 2) is located at N'Toum locality, which is situated at $40 \mathrm{~km}$ of Libreville at GPS coordinates $0^{\circ} 58^{\prime} 42.9^{\prime \prime} \mathrm{N}, 9^{\circ} 41^{\prime} 58.49^{\prime} \mathrm{E}$. It is $10 \mathrm{~m}$ thick and composed of beige, light grey limestones intercalated with dark marls. Texture of limestones and marls is mudstone to packstone. The deposits, which contain plant debris, gastropods, ostracods, ammonites, echinoderms and bivalves, are assigned to Albian age by their ammonite fauna (Hourcq and Hausknecht, 1954; Hudeley and Belmonte, 1970) such as Douvilleiceras monile (Sowerby, 1816) and D. mamillatum (Schlotheim, 1813).

\section{Material and methods}

The material for this study comprises 16 specimens from $\mathrm{N}$ 'Toum quarry section. In general, all specimens are preserved as internal moulds. Some specimens are laterally deformed due to compaction. 


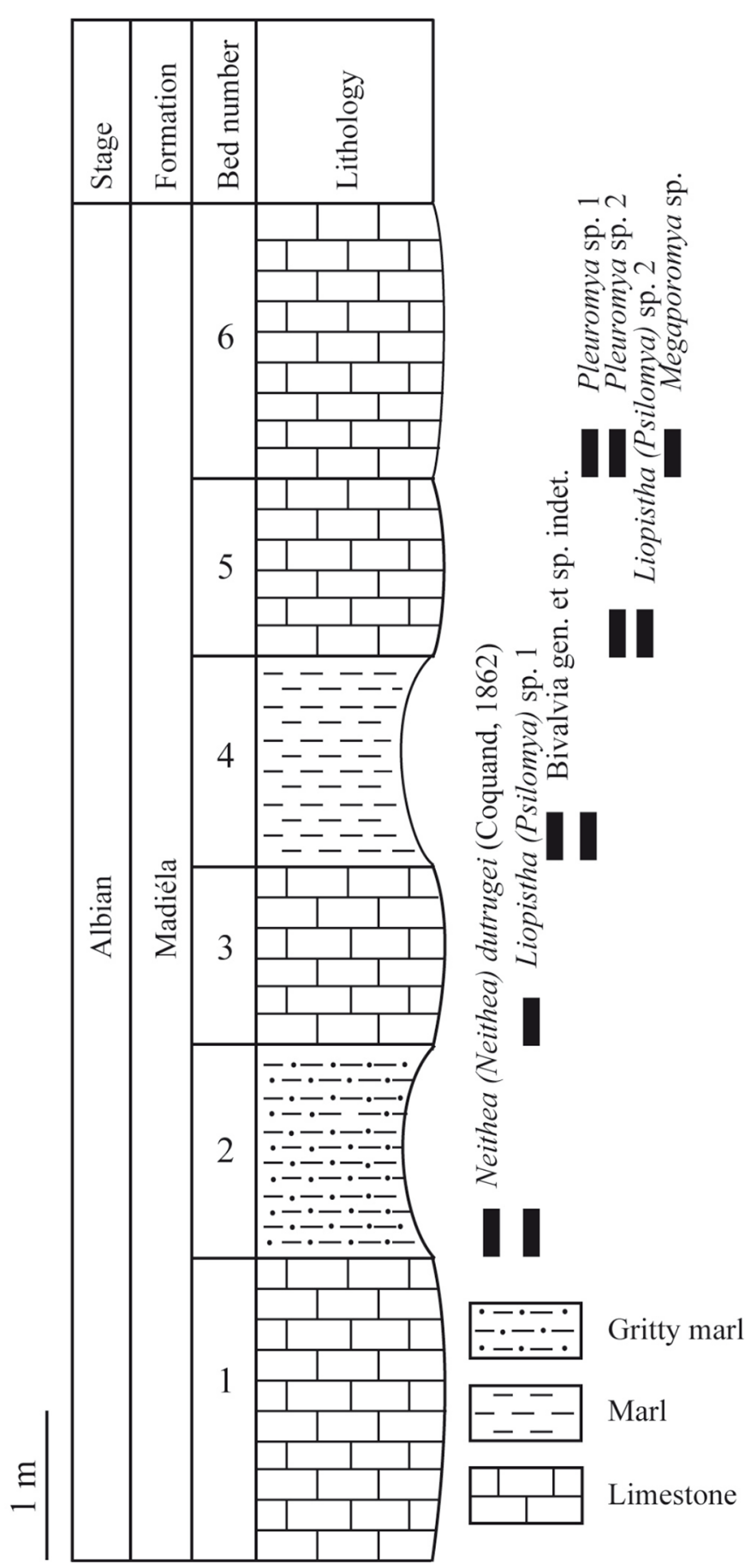

Fig. 2. Lithostratigraphy of the N'Toum quarry section indicating the occurrence of bivalves fauna.

Linear measurements are in millimeters. Abbreviations of measured parameters: L: shell length; $\mathrm{H}$ : shell height; W: width of articulated valves.

The systematic classification follows that of Carter et al. (2011). The morphological terminology follows the glossary of Cox (1969) in the Treatise on Invertebrate Paleontology.

The material is deposited at the collection of the Geology Department, Faculty of Sciences Masuku University of Franceville (Gabon), under collection number MDG/GBN/Lm.
Here we describe species which are mentioned for the first time in the Albian of the Gabonese coastal basin.

\section{Systematic palaeontology}

Order Pectinida Gray, 1854

Superfamily Pectinoidea Rafinesque, 1815

Family Pectinidae Rafinesque, 1815

Genus Neithea Drouet, 1824

Type species Pecten aequicostatus Lamark, 1819

Diagnosis. Shell equivalved, equilateral to asymmetrical, auriculated; rihgt valve more convex than left valve ended by umbo; hing with two diverging, transversal striated cardinal teeth; equal or nearly aqual radial ribs (Drouet, 1824 enlarged by Dhondt, 1973).

Species included. Pecten aequicostatus Lamark, 1819, Pectinites regularis, Schlotheim, 1813, Janira alpina, D’Orbigny, 1847, J. dutrugei Coquand, 1862, J. tricostata, Coquand, 1862, J. hispánica, D’Orbigny, 1850).

Remarks. In Gabon, this genus is represented only by one species recorded in Aptian (Dartevelle and Freneix, 1957 and this study).

Occurrence. Cretaceous (Neocomian - Senonian).

Subgenus Neithea Drouet, 1824

Type species. Pecten aequicostatus Lamark, 1819

Neithea (Neithea) dutrugei (Coquand, 1862)

Fig. 3.4

1862 Janira dutrugei sp. nov. Coquand, p. 219, pl. 13, figs. $1-2$.

1918 Pecten (Neithea) dutrugei (Coquand): Greco, p. 24, pl. 3(19), figs. 7-9.

1934 Pecten (Vola) dutrugei Coquand: Blanckenhorn, p. 192, pl. 9, fig. 25.

1957 Neithea shawi Pervinquière: Dartevelle \& Freneix, p. 74, pl. 9, figs. 8-11.

1993 Neithea (Neithea) dutrugei (Coquand): Dhondt \& Dieni, p. 190, pl. 4, fig. 17, text-fig.4.

2006 Neithea (Neithea) dutrugei (Coquand): Perrillat et al., p. 101, figs. 14-16.

2007 Neithea (Neithea) dutrugei (Coquand): Mekawy, p. 101, figs. 14-16.

2011 Neithea (Neithea) dutrugei (Coquand): Ayoub Hannaa, p. 107, pl. 9, fig. 10, text-fig. 3.12.

Material. 1 specimen from bed 2 (MDG/GBN/Lm - 57.1). It is represented only by its right valve, by preventing any measure of shell width.

Measurements (in mm): $\mathrm{L}=20 ; \mathrm{H}=29$.

Remarks. The specimen of this study resembles to species from the Cenomanian of Egypt (Ayoub-Hannaa, 2011 p. 107, p. 9, fig. 10) in outline and in having numerous irregular ribs (both primary and intercalatory ribs).

Occurrence. Upper Cretaceous of North Africa (Coquand, 1862; Greco, 1918; Mekawy, 2007; Ayoub-Hannaa, 2011), Lower Turonian of Jordan (Perrilliat et al., 2006), Cenomanian of Syria, Palestine and Italy (Blanckenhorn, 1934; Dhondt and Dieni, 1993), Albian of Gabon (Dartevelle and Freneix, 1957; this study).

Order PHOLADOMYOIDA Newell, 1965

Superfamily PHOLADOMYOIDEA King, 1844 


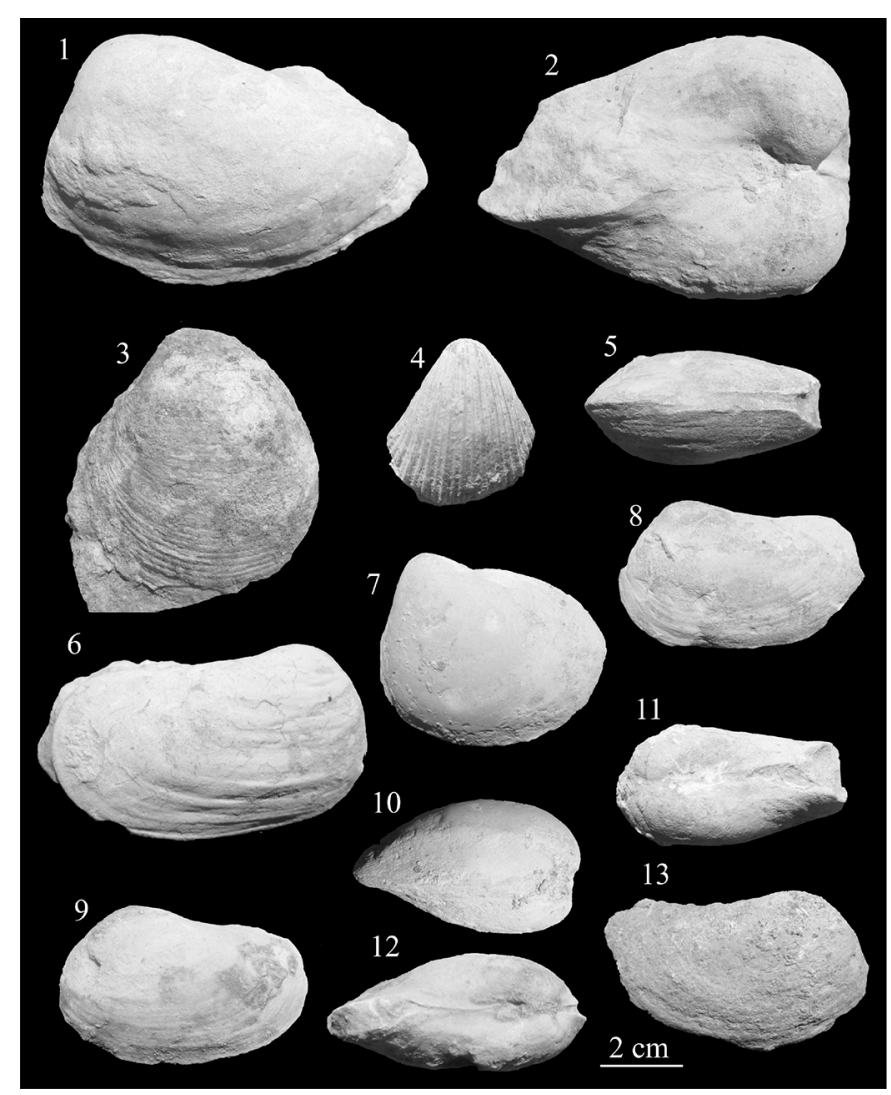

Fig. 3. 1-2, Megaporomya sp. (MDG/GBN/Lm - 60.1), left valve in 1: lateral view; 2: dorsal view; 3: Bivalvia gen. et sp. indet. (MDG/GBN/ Lm - 63.1), left valve in lateral view; 4: Neithea (Neithea) dutrugei (Coquand, 1862) (MDG/GBN/Lm - 57.1), left valve in lateral view; 5, 8, 11: Pleuromya sp. 16 (MDG/GBN/Lm - 58.1), left valve in 5: ventral view, 8: lateral view, 11: dorsal view; 6, 9, 12: Pleuromya sp. 2, 6: right valve (MDG/GBN/Lm - 59.2) in lateral view; 9 and 12: left valve (MDG/GBN/Lm - 59.1) in lateral and dorsal view; 7, 10: Liopistha $($ Psilomya) sp. 1 (MDG/GBN/Lm - 61.1), left valve in 7: lateral view; 10: dorsal view; 13: ? Liopistha (Psilomya) sp. 2 (MDG/GBN/Lm 61.1), right valve in lateral view.

Family Pleuromyidae Zittel, 1895

Genus Pleuromya Agassiz, 1842

Type species. Mya gibbosa Sowerby, 1823

Diagnosis. Shell of large size, equivalve, oval, elongate, thin, moderately to strongly inflated, with narrow to moderately wide anterior and posterior gape; umbones prosogyrate contiguous, situated toward anterior end of shell; Surface with concentric ribbing (Agassiz, 1842)

Species included. Pleuromya africana (Etheridge, 1907), P. congoensis Dartevelle and Frenix, 1957.

Remarks. In Gabon, this genus is represented only by species Pleuromya congoensis Dartevelle and Freneix, 1957 recorded in Turonian of Libreville (Dartevelle and Freneix, 1957). Here, it is found for the first time in Aptian.

Occurrence. Trias to Coniacian

\section{Pleuromya sp. 1}

Fig. 3.5, 3.8, 3.11

Material. 3 specimens from beds 4 and 6 (MDG/GBN/Lm - 58.1 to 58.3$)$.

Measurements (in $\mathrm{mm}): \mathrm{L}=42-53$ (mean $=47.5) ; \mathrm{H}=26$ $28($ mean $=27) ; \mathrm{W}=20-26($ mean $=23)$.

Description. Shell large, elongate-ovate, strongly inequilateral, equivalved, little inflated. Maximum inflation slightly below umbonal area, decreasing gradually towards posterior end. Umbonal area wide and inflated. Beaks prominent, prosogyrate, situated one-fourth of the total valve length from the anterior end. Anterior and posterior margins rounded, joining ventral margin in rounded angle. No lunule. Anterodorsal margin truncated obliquely, joining anterior margin in acute angle. Postero-dorsal margin slightly concave. Posterior end wadely gaping. This gap extends until postero-ventral margin where becomes narrow. Ventral margin straight to sighlty convex. Ornament consisting of fine, commarginal folds separated by regular interspaces. Ribs erasing towards umbonal area.

Remarks. Pleuromya sp. 1 shows some similarities to Pleuromya ligeriensis (d'Orbigny, 1845) from the upper Cenomanian-lower Turonian of Sergipe, Brazil (AyoubHannaa et al., 2013, p. 50, figs. 11I-J) in general outline and in having fine commarginal folds but differs in lacking fine commarginal folds towards umbonal area and in having gap in postero-ventral margin.

P. congoensis Dartevelle and Freneix, 1957 from the Turonian of Gabon and Cenomanian to Maastrichtian of Democratic Republic of Congo (Dartevelle and Freneix, 1957, p. 208, pl. 32, figs. 9-10; pl. 33, figs; 1-2) differs in having narrow gap both posteriorly and anteriorly. 
Occurrence. Albian of Gabon (this study). In Gabon, this species is found for the first time.

Pleuromya sp. 2

Fig. 3.6, 3.9, 3.12

Material. 4 specimens from beds 5 and $6(\mathrm{MDG} / \mathrm{GBN} / \mathrm{Lm}$ - 59.1 to 59.4).

Measurements (in mm): $\mathrm{L}=30-44$ (mean $=38.5) ; \mathrm{H}=19$ $28($ mean $=23.5) ; \mathrm{W}=14-22($ mean $=18)$.

Description. Shell large, elongate-ovate to oblong, strongly inequilateral, nearly equivalved, inflated. Maximum inflation slightly below umbonal area, decreasing gradually towards posterior end. Umbonal area wide and inflated. Beaks prominent, prosogyrate, situated one-fourth of the total valve length from the anterior end. Anterior and posterior margins rounded, joining ventral margin in nearly rounded angle. No lunule. Antero-dorsal margin short, straight, joining anterior margin in rounded angle. Postero-dorsal margin straight. Anterior and posterior margins slightly gaping. Ornament consisting of fine commarginal folds.

Remarks. Pleuromya sp. 2 differs with Pleuromya sp. 1 in having anterior and posterior margins slightly gaping.

Occurrence. Albian of Gabon (this study). In Gabon this species is found for the first time.

\section{Superfamily POROMYOIDEA Dall, 1886}

Family POROMYIDAE Dall, 1886

Genus Megaporomya Ayoub-Hannaa et al., 2013

Type species. Megaporomya reymenti Ayoub-Hannaa et al., 2013

Diagnosis. Thin-shelled, large to very large; variable in outline; strongly inflated anteriorly (cordate in cross-section), posteriorly elongate and compressed; umbones wide, strongly convex, enrolled; posterior siphonal gape wide; anisomyarian with shallow pallial sinus; hinge of right valve consisting of one large, inverted, U-shaped cardinal tooth, one straight and narrow cardinal tooth and two unequal sockets; hinge of left valve with two unequal teeth and sockets (Ayoub-Hannaa et al., 2013).

Species included. Megaporomya reymenti Ayoub-Hannaa et al., 2013.

Remarks. Megaporomya has been erected by AyoubHannaa et al. (2013) within Upper Turonian of Sergippe basin (Brazil). It is found here for the first time in Gabonese coastal basin.

Occurrence. Upper Albian of Morrocco (Benzaggagh, 2016); Upper Turonian of Brazil (Ayoub-Hannaa et al., 2013)

\section{Megaporomya sp.}

Fig. 3.1-2

Material. 2 specimens from bed 5 (MDG/GBN/Lm -60.1 to 60.2 ).

Measurements (in mm): $\mathrm{L}=89 ; \mathrm{H}=46 ; \mathrm{W}=63$.

Description. Shell very large, elongate-ovate, globular, wider than high, slightly equivalved, strongly inequilateral, strongly inflated, slightly compressed posteriorly. Maximum inflation below the umbonal area. Umbonal area wide and strongly convex. Beaks large, prominent, slightly incurved anteriorly and situated approximately one-third of the total valve length from the anterior end. Anterior umbonal round ridge well-developed, extending from umbonal area to middle of anterior margin, forming boundary of shallow depression on anterior part. Anterior margin short, slightly convex, meeting the ventral margin in a blunt, nearly right angle. Posterior margin obliquely truncated, forming an acute angle with the ventral margin. Posterior end strongly gaping. Antero-dorsal margin straight, meeting the anterior margin in a rounded angle. Postero-dorsal margin straight to slightly convex, slightly sloping, forming an obtuse angle with the posterior margin. Ventral margin slightly convex. Ornamentation consisting of two strong commarginal ribs widely interspaced towards ventral margin.

Remarks. Megaporomya reymenti Ayoub-Hannaa et al. (2013) from Upper Turonian of Sergippe, Brazil resembles this species in outline and form and position of beaks but differs in lacking two strong commarginal folds widely interspaced towards ventral margin.

Occurrence. Albian of Gabon (this study). In Gabon, this species is found for the first time.

Genus Liopistha Meek, 1864

Type species Cardium elegantulum Roemer, 1852.

Diagnosis. Thin-shelled, ovate, posterior end somewhat attenuate; hinge with two cardinal teeth, no laterals; ligament external; pallial area indistinct (Keen in Newell, 1969).

Species included. L. (Liopistha) hourcqui Dartevelle and Freneix, 1957, L. (L.) ventricosa Koenen, 1897.

Remarks. In Gabon, this genus is represented by three species recorded in Senonian of Mikominzem, Gomé W and Cabane T17 (Dartevelle and Freneix, 1957).

Occurrence. Early to Late Cretaceous.

Subgenus Psilomya White, 1874

Type species. Liopistha (Psilomya) meekii White, 1874

Liopistha (Psilomya) sp. 1

Fig. 3.7, 3.10

Material. 2 specimens from beds 2 and 3 (MDG/GBN/Lm -61.1 to 61.2 ).

Measurements (in mm): $\mathrm{L}=28-33$ (mean $=30.5$ ); $\mathrm{H}=22$ $28($ mean $=24) ; \mathrm{W}=15-20($ mean $=17.5)$.

Description. Shell medium to large-sized, subtrigonal to transversely oblong, inequilateral, slightly inequivalved, strongly compressed posteriorly, moderately inflated with maximum inflation slightly below umbonal area. Umbonal area broad and slightly convex. Beaks prominent, elevated above hinge line, sharply pointed, prosogyrate, situated approximately one-fourth of the total valve length from the anterior end. Anterior umbonal ridge well-developed, extending from umbonal area to anterior end, forming boundary of deep depression on anterior part. Posterior umbonal ridge welldeveloped. Anterior end short slightly rounded, joining ventral margin in rounded curve. Posterior end elongate. No posterior gap. Anterodorsal margin short, straight, joining anterior end in obtuse angle. Postero-dorsal margin straight to slightly concave, gradually sloping towards posterior margin. Ventral margin broadly rounded. Shell smooth.

Remarks. This species shows some similarities to Liopistha (Psilomya) concentrica Stanton, 1894 from the upper Cenomanian-lower Turonian of Sergipe, Brazil (AyoubHannaa et al., 2013, p. 56, figs. 11M-N) in general outline, size and lacking radial ribbing but differs in being more inflated ( $\mathrm{W} / \mathrm{L}=0.56$ on average as opposed to 0.42 ) and in lacking regular growth rugae. 
L. (Liopistha) hourcqui Dartevelle and Freneix, 1957 from the Senonian of Gabon (Dartevelle and Freneix, 1957, p. 218, pl. 33, fig. 10) differs in having radial ribs.

Occurrence. Albian of Gabon (this study).

? Liopistha (Psilomya) sp. 2

Fig. 3.13

Material. 2 specimens from bed $5(\mathrm{MDG} / \mathrm{GBN} / \mathrm{Lm}-62.1$ to 62.2 ).

Measurements (in mm): $\mathrm{L}=42-48$ (mean $=45) ; \mathrm{H}=23-30$ $($ mean $=26.5) ; \mathrm{W}=18-22($ mean $=20)$.

Description. Shell large-sized, elongate-ovate, strongly inequilateral, slightly inequivalved, strongly compressed posteriorly, moderately inflated with maximum inflation slightly below umbonal area. Umbonal area broad and slightly convex. Beaks prominent, elevated above hinge line, prosogyrate, situated approximately one-third of the total valve length from the anterior end. Escutcheon narrow, elongate and shallow. Anterior end short slightly rounded, joining ventral margin in rounded curve. Posterior end elongate. No posterior gap. Anterodorsal margin short, straight, steeply sloping towards anterior margin. Postero-dorsal margin straight to slightly concave. Ventral margin rounded. Ornament consisting of weak irregular commarginal folds.

Remark. By its strongly compressed posterior end and well-developed prosogyrate beaks, specimens recorded herein resembles to Liopistha (Psilomya) genus to which it is questionably assigned because of the absence of lessdeveloped radial ornament. It differs from Liopistha (Psilomya) concentrica Stanton, 1894 in having elongate ovate shell and weak irregular commarginal ribs. ? Liopistha (Psilomya) sp. shows similarities with Liopistha (Psilomya) elongata Stanton, 1894 but differs in lacking faint axial tubercles.

Occurrence. Albian of Gabon (this study). In Gabon, this species is found for the first time.

Bivalvia gen. et sp. indet.

Fig. 3.3

Material. 2 specimens from bed $4(\mathrm{MDG} / \mathrm{GBN} / \mathrm{Lm}-63.1$ to 63.2 ). They are represented by their left valve, by preventing any measure of shell width.

Measurements (in mm): $\mathrm{L}=56 ; \mathrm{H}=65$.

Description. Shell large-sized, subtrapezoidal, inequilateral, inflattened, with well-marked dorsal areas. Beack prominent, prosogyrate, placed anterior, slightly incurved. Anterodorsal margin strongly to weakly concave; posterodorsal weakly convex. Anterior margin rounded in outline. Posterior margin evenly rounded, passing smoothly into weakly convex ventral margin. Inflation located at around $30 \%$ of height below dorsal extremity of umbones. Ornamentation consisting of spaced concentric lamellae. Area smoother than remainder of disc.

Remark This morphotype shows some similarities to genus Lucina Bruguière, 1797 in general outline and in having dorsal area and concentric lamellae but the poor preservation doesn't permit to distinguish ligament, hinge and muscle scars which are others capital characters form this genus.

Occurrence. Albian of Gabon (this study).

\section{Discussion}

\subsection{Diversity and abundance}

The bivalve fauna recorded from the N'Toum quarry geological section is composed of seven species including five genera and four families (Fig. 2). Bivalve faunas previously described and illustrated from the Madiela Formation (Choubert, 1935; Hourcq, 1943; Dartevelle and Brébion, 1957) differ with the one described from N'Toum quarry geological section herein. The particularity of the latter one is the presence of Liopistha (Psilomya) sp. 1, ? Liopistha (Psilomya) sp. 2, Megaporomya sp., Pleuromya sp. 1, Pleuromya sp. 2 and Bivalvia gen. et sp. indet. Now, a total of twelve species of bivalves have been reported from the Madiela Formation.

From the abundance point of view, the bivalve fauna from N'Toum quarry geological section is characterized by low abundance. Only 15 specimens have been recorded. This fauna is dominated by representatives of Pleuromyidae Zittel, 1895 and Poromyidae Dall, 1886 families with respectively 7 and 6 specimens. The other families are represented by one or two specimens. At a generic level, only Pleuromya has more five specimens.

\subsection{Distribution and stratigraphy}

From Gabon, the genera Liopistha and Pleuromya are only known respectively within the Senonian and Turonian (Dartevelle and Freneix, 1957). The N'Toum quarry geological section, which is assigned to the Albian, provides representatives of the genera Liopistha and Pleuromya. Their presence permits us herein to expand their geographical distribution until N'Toum regions, and their age range to Albian.

The genus Megaporomya, erected by Ayoub-Hannaa et al. (2013) in upper Turonian of Brazil, has been recorded in Albian of Morrocco (Benzaggagh, 2016). In Gabon, this is the first record of this genus.

\section{Conclusion}

The study of Albian bivalves from the Madiela Formation from N'Toum quarry geological section reveals the following conclusions:

- in comparison with previous studies of bivalve fauna from the Albian Madiela Formation, bivalves from N'Toum quarry section differ on its systematic content;

- the fauna of N'Toum quarry geological section is dominated by representatives of Pleuromyidae Zittel, 1895 and Poromyidae Dall, 1886 families;

- in Gabon, the stratigraphic and geographic range of Liopistha and Pleuromya genera are extended into Albian and N'Toum region respectively;

- Megaporomya genus is recorded herein for the first time in the Gabonese coastal basin.

Acknowledgements. I am grateful to all reviewers and the Journal editorial board for their constructive comments which greatly improved the manuscript. 


\section{References}

Agassiz JL. 1842 Études critiques sur les mollusques fossiles. In Sowerby J, ed. Mineral Conchology (French edition), 1842-1844: Neuchâtel, Monographie des Myes, Solothurn bei Jent \& Gassmann, 287 p.

Ayoub-Hannaa WS. 2011. Taxonomy and Palaeoecology of the Cenomanian-Turonian Macro-Invertebrates from Eastern Sinai, Egypt. Thèse de Bayerischen Julias-Maximilians-Universität Würzburg, $386 \mathrm{p}$.

Ayoub-Hannaa WS, Bengtson P, Fürsich FT, Andrade EJ. 2013. Megaporomya reymenti gen. et sp. nov. (Bivalvia, Pholadomyida) from the upper Turonian (Upper Cretaceous) of the Sergipe Basin, north-eastern Brazil. Rev Bras Paleontol 16: 197-212. DOI: 10.4072/rbp.2013.2.03.

Benzaggagh M. 2016. Bivalves crétacés de la Formation des Marnes et calcaires lumachelles à huîtres (Albien supérieur-Cénomanien inférieur) des Rides sud-rifaines (région de Moulay Idriss Zerhoun, nord Maroc). Ann Paleonto 102: 183-211. DOI: 10.1016/j. annpal.2016.08.003.

Blanckenhorn M. 1890. Beiträge zur Geologie Syriens: Die Entwickelung des Kreidesystems in Mittel-und Nord-Syrien mit besonderer Berücksichtigung der paläontologischen Verhältnisse nebst einem Anhang über den jurassischen Glandarienkalk. Cassel, $135 \mathrm{p}$.

Blanckenhorn M. 1934. Die Bivalven der Kreideformation von SyrienPalästina nebst einem ergänzenden Anhang über Brachiopoden, Gastropoden und Pteropoden und einem Überblick über die gesamte Molluskenfauna. Palaeontographica, Abteilung A81: 161-296.

Bruguière JB. 1797. Encyclopédie méthodique ou par ordre de matières. Histoire naturelle des vers, des mollusques. Atlas, part 2. Panckoucke. Paris, pp. 190-286.

Carter JG, Altaba CR, Anderson LC, Araujo R, Biakov AS, Bogan AE, et al. 2011. A synoptical classification of the Bivalvia (Mollusca). - Paleontological Contributions 4. Kansas University Paleontological Institute. Lawrence, Kansas: The University of Kansas, 47 p. DOI: 10.17161/PC.1808.8287.

Chevalier L, Makanga JF, Thomas RJ. 2002. Carte géologique de la République gabonaise au $1 / 1000000$. Notice explicative. Council for geoscience, $195 \mathrm{p}$.

Choubert B. 1935. Sur les terrains crétacés de la zone côtière du Gabon. C R Acad Sci Paris 201: 401-403.

Coquand H. 1862. Géologie et Paléontologie de la région sud de la Province de Constantine. Marseille: 343 p.

Cox LRL. 1969. Morphological terms applied to bivalve shells and soft parts affecting shell. In: Moore RC, ed. Treatise on Invertabrate Paleontology, Part N (Mollusca 6, Bivalvia). Boulder: Geological Society of America and Lawrence K.S., University of Kansas Press, pp. N1-N489.

Dall W. 1886. Report on the Mollusca. Part 1. Brachiopoda and Pelecypoda. In Reports on the results of dredging, under the supervision of Alexander Agassiz, in the Gulf of Mexico (1877-1878) and in the Caribbean Sea (1879-1880) by the U.S. Coast Survey Steamer "Blake, " Lieut. -Commander C.D. Sigsbee, U.S.N., and Commander J.B. Bartlet, U.S.N., commanding. $1886+1889$. Harvard College. Mus Com Zoo Bull 12(6): 171-318.

Dartevelle E, Brébion P. 1956. Mollusques fossiles du Crétacé de la côte occidentale d'Afrique du Cameroun à l'Angola. I. Gastéropodes. Ann Mus Roy Congo belge, Sciences géologiques, 15: 128 p.

Dartevelle E, Freneix S. 1957. Mollusques fossiles du Crétacé de la côte occidentale d'Afrique du Cameroun à l'Angola. II. Lamellibranches. Ann Mus Roy Congo belge, Sciences géologiques, 20: $271 \mathrm{p}$.
Dhondt AV. 1973. Systematic revision of the subfamily Neitheinae (Pectinidae, Bivalvia, Mollusca) of European Cretaceous. Inst Roy Sci Nat Belgique Memoire 176: 5-101.

Dhondt AV, Dieni I. 1993. Non-rudistid bivalves from Late Cretaceous rudist limestones of NE Italy (Col dei Schiosi and Lago di S. Croce areas). Mem Sci Geo 45: 165-241.

Drouet C. 1824. Sur un nouveau genre de coquille de la famille des Arcacées et description d'une nouvelle espèce de Modiole fossile. Mem Soc linn Paris 3: 183-192.

Dupont G. 1996. Principaux foraminifères planctiques du Crétacé gabonais (Aptien à Campanien inférieur). In Jardiné S, Klasz I, Debenay JP, eds. Géologie de l'Afrique et de l'Atlantique Sud. Actes Colloques Angers 1994, pp. 83-121.

Etheridge R. 1907. Cretaceous fossils of Natal, part II: The Umsinene River Deposit. Third Rep Geol Surv Natal Zululand 67-90.

Goldfuss A. 1837. Petrefacta Germaniae 2: 141-224.

Gray JE. 1854. List of the shells of Cuba in the collection of the British Museum, collected by M. Ramon de la Sagra, described by Prof. Alcide d'Orbigny, in the Histoire de l'Île de Cuba. London, British Museum, 48 p.

Greco B. 1918. Fauna cretacea dell'Egitto raccolta dal Figari Bey Parte terza: Lamellibranchiata (cont. e fine). Fasc. 2 Lamellibranchi del Turoniano e del Cenomaniano. Palaeontogr Ital 24: 1-58.

Grosdidier E. 1979. Principaux ostracodes marins de l'intervalle Aptien-Turonien du Gabon (Afrique occidentale). Bull Centres Rech Expl Prod Elf Aquitaine 3(1): 1-35.

Hourcq V. 1943. Les terrains sédimentaires de la région côtière de l'Afrique Equatoriale Française. Gouvernement Général AEF. Bull Services Mines 1: 67-96.

Hourcq V. 1952. Les terrains sédimentaires de la région côtière de l'AEF - Notice explicative de la carte géologique de l'AEF et du Cameroun au 1/2 000000 , pp. 69-109.

Hourcq V, Hausknecht JJ. 1954. Notice explicative sur la faille LibrevilleOuest et carte géologique de reconnaissance au 1/500 000. Paris: Gouvernement Général de l'Afrique Equatoriale Française, 25 p.

Hudeley H, Belmonte Y. 1970. Carte géologique de la République gabonaise au 1/1 000 000. Notice explicative. BRGM Mem 72: $191 \mathrm{p}$.

King W. 1844. On a new genus of Palaeozoic shells. Ann Mag Nat History 14(1): 313-317.

Koenen A. 1897. Ueber Fossilien der unteren Kreide am Ufer des Mungo in Kamerun. Abh Ges Wiss Gôttingen B.1: 1-48.

Lamarck JB. 1819 Histoire naturelle des animaux sans vertèbres. Bivalvia 6, 1-233.

Lanau M. 1985. Sédimentation et diagenèse d'une série hypersiliceuse: le groupe d'Ozouri, Paléocène supérieur - Eocène inférieur du bassin côtier gabonais. Thèse Univ. Poitiers, 258 p.

Mbina Mounguengui M. 1998. Dynamique sédimentaire et fluctuations eustatiques au cours du Cénomanien et Turonien basal dans le Nord du bassin côtier gabonais. Thèse Univ. Bourgogne, $376 \mathrm{p}$.

Mbina Mounguengui M, Lang J, Guiraud M, Jocktane O. 2002. Sedimentary dynamics and structural geology of pre-rift deposits of interior basin of Gabon. J Afr Earth Sci 35: 315-329.

Mbina Mounguengui M, Lang J. 2003. Evolution de la dynamique sédimentaire au cours du Cénomanien et du Turonien dans le Nord du bassin côtier gabonais. Afr Geol Rev 10(1 \& 2), 85-102.

Meek FB. 1864. Check list of the invertebrate fossils of North America. Cretaceous and Jurassic. Smithsonian Misc Coli 177: 40 p.

Mekawy MS. 2007. Upper Cretaceous bivalves from Galala Plateaux, North Eastern Desert, Egypt: a systematic paleontology. Egypt $J$ Geol 7: 197-243.

Musavu Moussavou B, Mabicka Obame R. 2015. Taxonomy and paleoecology of Albian Madiela Formation gastropods, Gabonese coastal basin: N'Toum quarry section. Bull Soc Geol Fr 186(1): 35 42. DOI: $10.2113 /$ gssgfbull.186.1.35. 
Newell ND. 1965. Classification of Bivalvia. Amer Mus Nov 2206: 1-25. Newell ND. 1969. Subclass Palaeoheterodonta Newell, 1965, and Order Modiomorphoida Newell, new order. In: Moore RC, ed. Treatise on Invertebrate Paleontology, Part N. Mollusca 6, Bivalvia, v. 1. Lawrence: Geological Society of America and University of Kansas Press, p. N393.

D’Orbigny A. 1850. Prodrome de paléontologie stratigraphique universelle des animaux mollusques et rayonnés. II: Bivalvia cretácica, $257 \mathrm{p}$.

Perrilliat MC, Ahmad F, Vega FJ. 2006. Upper Cretaceous (Cenomanian-Turonian) bivalves from northern Jordan, Middle East. Rev. Mex. Cien. Geol 23, 96-106.

Rafinesque C. 1815. Analyse de la nature. Palermo, 225 p.

Roemer FA. 1852. Die Kreidebildungen von Texas und ihre organischen Einschlüsse. Bonn, Adolph Marcus, 100 p.

Schlotheim E.F. 1813. Beitrage zur Naturgeschichte der Vernsteirungen in geognostischer Hinsicht. In: Leonhard $\mathrm{CC}$, ed.
Taschenbuch für die gesammte Mineralogie mit Hinsicht auf die neuesten Entdeckungen herausgegeben von Dr. Carl Caesar Leonhard, pp. 3-134.

Sowerby J. 1816. The mineral conchology of Great Britain. London: B. Meredith, 2, pp. 29-116.

Sowerby J. 1823. The Mineral Conchology of Great Britrain; or Colored Figures and Descriptions of those remains of Testaceous Animals or shells which have been preserved at various times and depth in the Earth, 4. London: B. Meredith.

Teisserenc P, Villemin J. 1990. Sedimentary basin of Gabon Geology and oils systems. In Edwards JD, Santogrossi PA, eds. Divergent/passive margin basins. Bull. Am. Ass. Petrol. Geol. mem. 48, 117-199.

White CA. 1874. Preliminary report on invertebrate fossils. U.S. Geog. Geol. Surveys W. 100th Meridian (Wheeler), 27 p.

Zittel KA. 1895. Grundzüge der Paläontologie (Paläozoologie), I Abteilung, Invertebrata. München and Leipzig, Oldenburg, 971 p.

Cite this article as: Musavu Moussavou B. 2019. Albian bivalves from Madiela Formation in north Gabonese coastal basin, $B S G F-E a r t h$ Sciences Bulletin 190: 5. 